\title{
Immunogenicity of Biopharmaceuticals
}

\author{
D.K.Das \\ Post Graduate Department of Biotechnology, T.M.Bhagalpur University, Bhagalpur-812007.
}

\begin{abstract}
Modern biotechnology has resulted in a resurgence of interest in the production of new therapeutic agents using botanical sources. With nearly 500 biotechnology products approved or in development globally, and with production capacity limited, the need for efficient means of therapeutic protein production is apparent. Through genetic engineering, plants can now be used to produce pharmacologically active proteins, including mammalian antibodies, blood product substitutes, vaccines, hormones, cytokines, and a variety of other therapeutic agents. Efficient biopharmaceutical production in plants involves the proper selection of host plant and gene expression system, including a decision as to whether a food crop or a non-food crop is more appropriate. Product safety issues relevant to patients, pharmaceutical workers, and the general public must be addressed, and proper regulation and regulatory oversight must be in place prior to commercial plant-based biopharmaceutical production. Plant production of pharmaceuticals holds great potential, and may become an important production system for a variety of new biopharmaceutical products.
\end{abstract}

\section{INTRODUCTION}

The use of plants or their extracts for the treatment of human disease predates the earliest stages of recorded civilization, dating back at least to the Neanderthal period. By the $16^{\text {th }}$ century, botanical gardens provided a wealth of materia medica for teaching therapeutic use; and herbal medicine flourished until the $17^{\text {th }}$ century when more scientific 'pharmacological' remedies were discovered (1). Subsequently, the active principle in many medicinal plants was identified and in many cases, purified for therapeutic use. Even today, about one-fourth of current prescription drugs have a botanical origin (1).

Medicinal plants play a vital role for the development of new drugs. They produce different drugs for the remedy of different diseases in human beings. These are ectoposide; E-guggulsterone, teniposide, nabilone, plaunotol, Z-guggulsterone, lectinan, artemisinin and ginkgolides appeared all over the world. 2\% of drugs were introduced from 1991 to 1995 including paciltaxel, toptecan, gomishin, irinotecan etc. Plant based drugs provide outstanding contribution to modern therapeutics; for example: serpentine isolated from the root of Indian plant Rauwolfia serpentina in 1953, was a revolutionary event in the treatment of hypertension and lowering of blood pressure. Vinblastine isolated from the Catharanthus rosesus (53) is used for the treatment of Hodgkins, choriocarcinoma, non-hodgkins lymphomas, leukemia in children, testicular and neck cancer. Vincristine is recommended for acute lymphocytic leukemia in childhood advanced stages of Hodgkins, lymophosarcoma, small cell lung, cervical and breast cancer. (54). Phophyllotoxin is a constituent of Phodophyllum emodi currently used against testicular, small cell lung cancer and lymphomas. Indian indigenous tree of Nothapodytes nimmoniana (Mappia foetida) are mostly used in Japan for the treatment of cervical cancer (Table 1).

Table 1 Some of the important medicinal plants used for major modern drugs for cancer

\begin{tabular}{|l|l|l|}
\hline Plant name/family & Drugs & Treatment \\
\hline Cathranthus rosesus L. (Apocynaceae) & Vinblastine and vincristine & $\begin{array}{l}\text { Hodgkins, Lymphosarcomas } \\
\text { and children leukemia. }\end{array}$ \\
\hline Podophyllum emodi Wall. (Beriberidaceae) & Podophyllotaxin, & $\begin{array}{l}\text { Testicular cancer, small cell } \\
\text { lung cancer and lymphomas. }\end{array}$ \\
\hline Taxus brevifolius (Taxaceae) & Paciltaxel, taxotere & $\begin{array}{l}\text { Ovarian cancer, lung cancer } \\
\text { and malignant melanoma. }\end{array}$ \\
\hline Mappia foetida Miers. & $\begin{array}{l}\text { Comptothecin, lrenoteccan and } \\
\text { topotecan }\end{array}$ & $\begin{array}{l}\text { Lung, ovarian and cervical } \\
\text { cancer. }\end{array}$ \\
\hline Comptotheca acuminata & $\begin{array}{l}\text { Quinoline and comptothecin } \\
\text { alkaloids }\end{array}$ & $\begin{array}{l}\text { used in Japan for the treatment } \\
\text { of cervical cancer }\end{array}$ \\
\hline Juniperus communis L. (Cupressaceae) & Teniposide and etoposide & Lung cancer \\
\hline
\end{tabular}


Plant derived drugs are used to cure mental illness, skin diseases, tuberculosis, diabetes, jaundice, hypertension and cancer. Medicinal plants play an important role in the development of potent therapeutic agents. Plant derived drugs came into use in the modern medicine through the uses of plant material as indigenous cure in folklore or traditional systems of medicine. More than 64 plants have been found to possess significant antibacterial properties; and more than 24 plants have been found to possess antidiabetic properties, antimicrobial studies of plants (55), plant for antiodotes activity - Daboia russellii and Naja kaouthia venom neutralization by lupeol acetate isolated from the root extract of Indian sarsaparilla Hemidesmus indicus R.Br (56). Which effectively neutralized Daboia russellii venom induced pathophysiological changes (57). The present investigation explores the isolation and purification of another active compound from the methanolic root extract of Hemidesmus indicus, which was responsible for snake venom neutralization. Antagonism of both viper and cobra venom and antiserum action potentiation, antioxidant property of the active compound was studied in experimental animals. Recently, (58) from this laboratory reported that an active compound from the Strychnus nux vomica seed extract, inhibited viper venom induced lipid peroxidation in experimental animals. The mechanism of action of the plant derived micromolecules induced venom neutralization need further attention, for the development of plant-derived therapeutic antagonist against snakebite for the community in need. However, the toxicity of plants has known for a long period of time, and the history of these toxic plants side by side with medicinal ones are very old and popular worldwide, they considered the major natural source of folk medication and toxication even after arising of recent chemical synthesis of the active constituents contained by these plants $(59,60,61)$. Traditional medicine is the synthesis of therapeutic experience of generations of practicing physicians of indigenous systems of medicine. Traditional preparation comprises medicinal plants, minerals and organic matters etc. Herbal drug constitutes only those traditional medicines that primarily use medicinal plant preparations for therapy. The ancient record is evidencing their use by Indian, Chinese, Egyptian, Greek, Roman and Syrian dates back to about 5000 years (Table 2).

Table 2: Plant derived ethnotherapeutics and traditional modern medicine

\begin{tabular}{|l|l|l|}
\hline S.No. & Drug & Basic investigation \\
\hline 1. & Codeine, morphin & $\begin{array}{l}\text { Opium the latex of Papaver somniferum used by ancient Sumarians. } \\
\text { Egyptaians and Greeks for the treatment of headaches, arthritis and } \\
\text { inducing sleep. }\end{array}$ \\
\hline 2 & Atropine, hyoscyamine & $\begin{array}{l}\text { Atropa belladona, Hyascyamus niger } \text { etc., were important drugs in } \\
\text { Babylonium folklore. }\end{array}$ \\
\hline 3 & Ephedrine & $\begin{array}{l}\text { Crude drug (astringent yellow) derived from Ephedra sinica had been } \\
\text { used by Chinese for respiratory ailments since 2700 BC. }\end{array}$ \\
\hline 5 & Quinine & $\begin{array}{l}\text { Cinchona spp were used by Peruvian Indians for the treatment of } \\
\text { fevers }\end{array}$ \\
\hline 6 & Emetine & $\begin{array}{l}\text { Brazilian Indians and several others South American tribes used root } \\
\text { and rhizomes of } \text { Cephaelis spp to induce vomiting and cure dysentery. }\end{array}$ \\
\hline 7 & Colchicine & $\begin{array}{l}\text { Use of Colchicum in the treatment of gout has been known in Europe } \\
\text { since 78 AD. }\end{array}$ \\
\hline & Digoxin & $\begin{array}{l}\text { Digitalis leaves were being used in heart therapy in Europe during the } \\
18 \text { century }\end{array}$ \\
\hline
\end{tabular}

Modern biotechnology has led to a resurgence of interest in obtaining new medicinal agents from botanical sources. Through genetic engineering (GE), plants can now be used to produce a variety of proteins, including mammalian antibodies, blood substitutes, vaccines and other therapeutic entities (2). Recently, the production of foreign proteins in genetically engineered (GE) plants has become a viable alternative to conventional production systems such as microbial fermentation or mammalian cell culture. GE plants, acting as bioreactors, can efficiently produce recombinant proteins in larger quantities than those produced using mammalian cell systems (3). Plant-derived proteins are particularly attractive, since they are free of human diseases and mammalian viral vectors. Large quantities of biomass can be easily grown in the field, and may permit storage of material prior to processing. Thus, plants offer the potential for efficient, large-scale production of recombinant proteins with increased freedom from contaminating human pathogens.

During the last two decades, approximately 95 biopharmaceutical products have been approved by one or more regulatory agencies for the treatment of various human diseases including diabetes mellitus, growth disorders, neurological and genetic 
maladies, inflammatory conditions, and blood dyscrasias $(4,6)$. -Some 500 agents are believed to be in development worldwide, with some 370 biopharmaceuticals in the US, including 178 agents directed against cancer or related conditions, 47 against infectious diseases, and the remainder for a variety of important medical conditions (Figure 1) (6). Among these, therapeutic entities are recombinant proteins, monoclonal antibodies, antisense oligonucleotides, and a variety of other protein agents such as hormones and immunomodulating drugs (Figure 2). This rapid increase in the number of new protein and peptide drugs reflects rapid advances in molecular biology, highlighted by the success of the human genome project that, in turn, will help to identify many additional opportunities for therapeutic intervention. Unfortunately, our capacity to produce these proteins in the quantities needed is expected to fall far short of demand by the end of the current decade (7). While none of the commercially available products are currently produced in plants, those biotechnology products, which are comprised of proteins, and possibly also DNA-based vaccines, are potential candidates for plant-based production.

Figure 1 Number of biopharmaceuticals under development, by disease class as of 2003 (6)

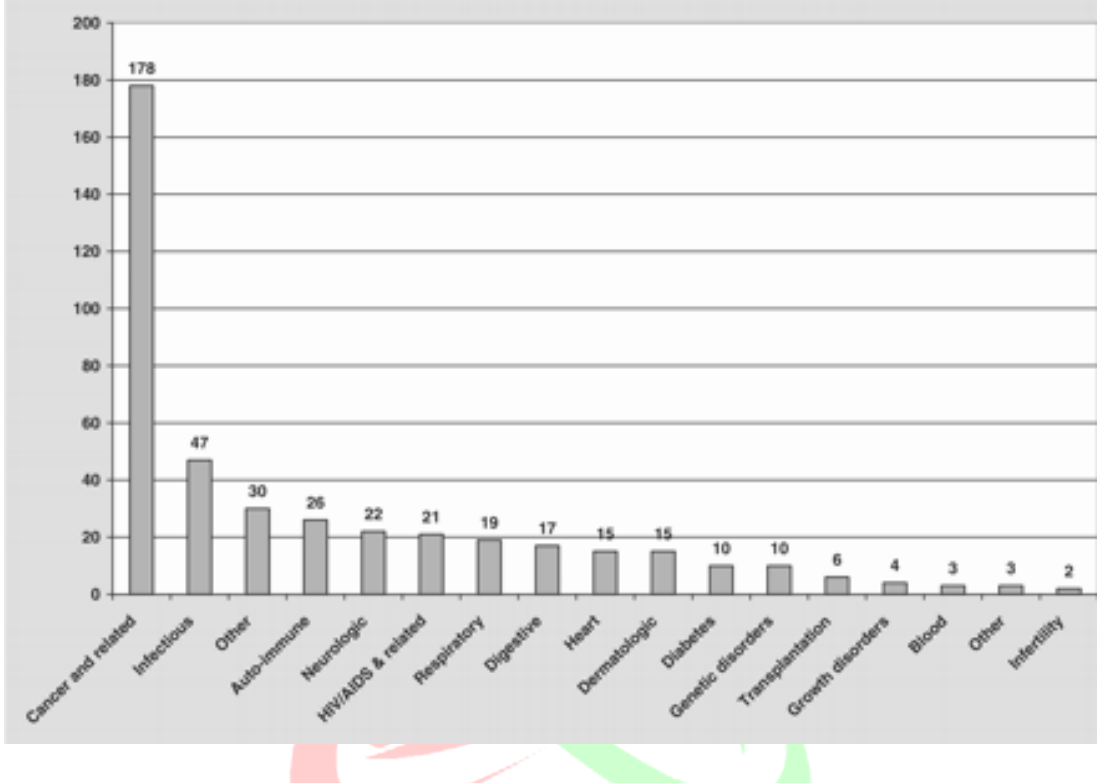

Figure 2. Number of biopharmaceuticals under development, by type of agent (6)

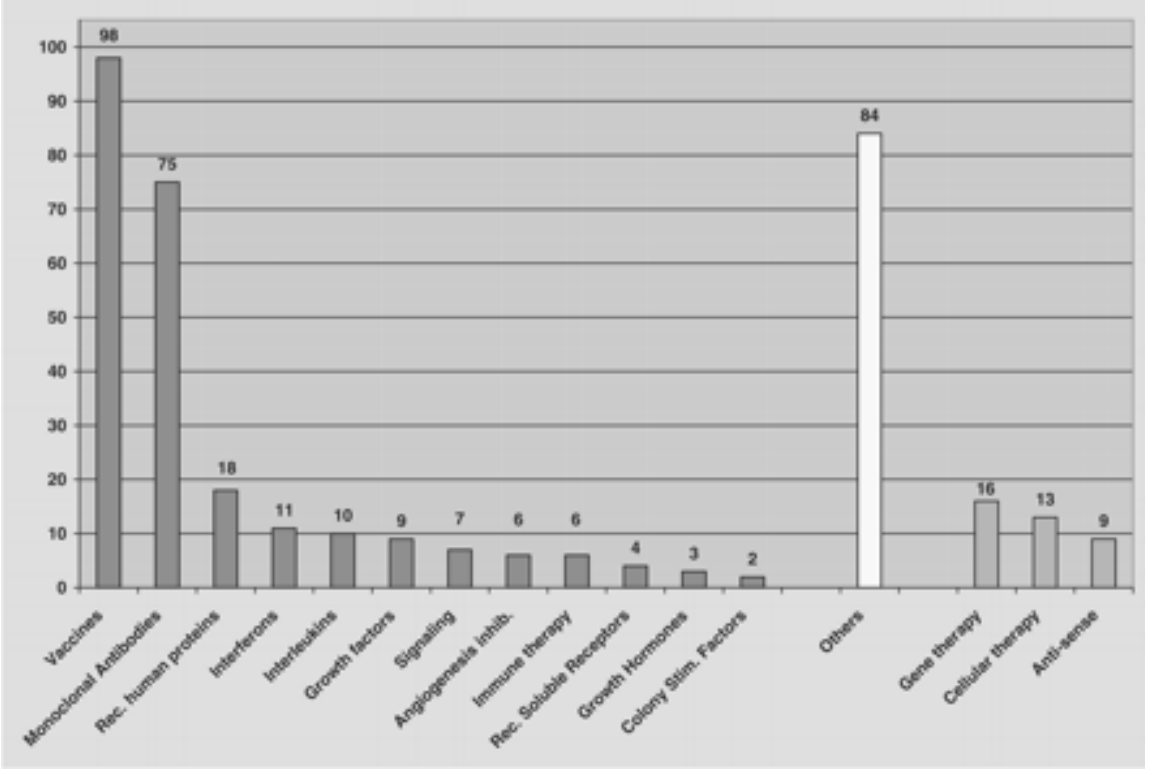


Advances in plant biotechnology have already resulted in plants that produce monoclonal antibodies or other therapeutic proteins, or that may serve as a source of edible vaccines. Research now underway will almost certainly result in GE plants designed to produce other therapeutic agents including hormones (e.g. insulin, somatotropin, erythropoietin), blood components, coagulation factors, and various interferons, and may well avoid critical limitations in production capacity.

Transgenic pharmaceutical plants are primarily modified by the introduction of novel gene sequences, which drive the production of 'designer' proteins or peptides. These proteins or peptides possess therapeutic value themselves, have properties that allow them to be used as precursors in the synthesis of medicinal compounds, or may serve as technical enzymes in pharmaceutical production. This review will attempt to catalogue the potential therapeutic applications of plant biotechnology and to address concerns related to the safety and efficacy of these agents in relation to human health and to specific disease states.

\section{The why and how of plant biotechnology}

Plant biotechnology can lead to the commercial production of pharmacologically important Therapeutic proteins, in many cases are fully functional and nearly identical to their mammalian counterparts (2). The application of plant biotechnology to produce hormones or other biologically active molecules began nearly 20 years ago, with a crucial advance being the expression of functional antibodies in plants, thereby demonstrating that plants could produce complex proteins of therapeutic significance (2). While bacteria are inexpensive and convenient production systems for many proteins (e.g. human insulin), they are incapable of the post-translational modification and assembly steps required for biological activity in more complex multi-component proteins such as antibodies (2). Plants exhibit an effective eukaryote protein synthesis pathway, and by combining currently available gene expression systems with appropriate acreage, plants can readily produce ton quantities of protein (2). Unlike mammalian cell systems, which can sometimes express pathogenic viral agents, plant systems are intrinsically free of mammalian pathogens (8). Thus, plant expression systems may offer advantages over bacterial and mammalian cell culture systems (Table 3 ) (2). 
Table 3. Comparison of recombinant protein production in plants, yeast and mammalian systems

\begin{tabular}{|c|c|c|c|c|c|c|}
\hline & $\begin{array}{l}\text { Transgenic } \\
\text { plants }\end{array}$ & $\begin{array}{l}\text { Plant } \\
\text { viruses }\end{array}$ & Yeast & Bacteria & $\begin{array}{l}\text { Mammalian } \\
\text { cell } \\
\text { eultures }\end{array}$ & $\begin{array}{l}\text { Transgeni } \\
\mathrm{c} \text { animals }\end{array}$ \\
\hline Cost/storage & Cheap/RT & $\begin{array}{l}\text { Cheap/- } \\
20^{\circ} \mathrm{C}\end{array}$ & $\begin{array}{l}\text { Cheap/- } \\
20^{\circ} \mathrm{C}\end{array}$ & $\begin{array}{l}\text { Cheap/- } \\
20^{\circ} \mathrm{C}\end{array}$ & Expensive & Expensive \\
\hline Distribution & Easy & Easy & Feasible & Feasible & Difficult & Difficult \\
\hline Gene Size & $\begin{array}{l}\text { Not } \\
\text { limited }\end{array}$ & Limited & Unknown & Unknown & Limited & Limited \\
\hline Glycosylation & 'Correct'? & 'Correct'? & Incorrect & Absent & 'Correct' & 'Correct' \\
\hline $\begin{array}{l}\text { Multimeric } \\
\text { protein } \\
\text { assembly } \\
\text { (SigA) }\end{array}$ & Yes & No & No & No & No & Yes \\
\hline $\begin{array}{l}\text { Produetion } \\
\text { cost }\end{array}$ & Low & Low & Medlum & Medlum & High & Hlgh \\
\hline $\begin{array}{l}\text { Production } \\
\text { scale }\end{array}$ & Worldwide & Worldwide & Limited & Limited & Limited & Limited \\
\hline $\begin{array}{l}\text { Production } \\
\text { vehicle }\end{array}$ & Yes & Yes & Yes & Yes & Yes & Yes \\
\hline Propagation & Easy & Feasible & Easy & Easy & Hard & Feasible \\
\hline $\begin{array}{l}\text { Protein } \\
\text { folding } \\
\text { accuracy }\end{array}$ & 'High'? & 'High'? & Medium & Low & High & High \\
\hline $\begin{array}{l}\text { Protein } \\
\text { homogeneity }\end{array}$ & 'High"? & Medium & Medium & Low & Medium & High \\
\hline Protein Yield & High & Very high & High & Medium & $\begin{array}{l}\text { Medium- } \\
\text { High }\end{array}$ & High \\
\hline $\begin{array}{l}\text { Public } \\
\text { perception of } \\
\text { risk }\end{array}$ & High & High & Medium & Low & Medium & High \\
\hline Safety & High & High & Unknown & Low & Medium & High \\
\hline $\begin{array}{l}\text { Scale-up } \\
\text { costs }\end{array}$ & Low & Low & High $* *$ & High** & High $* *$ & High \\
\hline $\begin{array}{l}\text { Therapeutic } \\
\text { risks* }\end{array}$ & Unknown & Unknown & Unknown & $\overline{Y e s}$ & Yes & Yes \\
\hline $\begin{array}{l}\text { Time } \\
\text { required }\end{array}$ & Medium & Low & Medium & Low & High & High \\
\hline
\end{tabular}

*Residual viral sequences, oncogenes, endotoxins; ${ }^{*}$ Large, expensive fermenters

Biopharmaceutical production in plants necessitates a series of careful decisions regarding three critical areas: (i) the gene expression system to be used, (ii) the location of gene expression within the plant, and (iii) the type of plant to be used.

There are a number of gene expression strategies that can be used to produce specific proteins in plants. With transient expression (TE), a gene sequence is inserted into plant cells using plant viruses, ballistic (gene-gun), or other methods, without incorporation of the new genetic material into the plant chromosome. TE systems can be rapidly deployed and can produce large amounts of protein (2) but because non-chromosomal DNA is not copied with the process of mitosis or meiosis, gene expression is neither permanent nor heritable. While TE systems are very useful for research and development, and may be useful for drug production, they require the fresh production of transformed plants with each planting and may be less attractive for long-term or high-volume protein production. 
Alternatively, the primary plant chromosome can be altered to allow for the permanent and heritable expression of a particular protein, i.e. allow the creation of plants, which produce seed carrying the desired modification. This can be done using Agrobacterium tumefaciens, a pathogen of plants that, in nature, transfers genetic material to the plant chromosome. By modifying the genetic content of Agrobacterium, desired genes can be readily inserted into many kinds of plants, especially dicots such as soybean. $(2,9)$ Genetic materials can also be coated onto small metallic pellets and introduced into cells ballistically using a 'gene-gun'(9). This latter system is useful for a wide variety of plant species. While permanent modification of the plant genome is more costly and time-consuming, it offers the clear advantage of stable, ongoing protein production with repeated planting alone.

Finally, systems exist that modify chloroplast DNA in plants and that can lead to heritable changes in protein expression (3). Plant chloroplasts may play a critical role in the future development of biopharmaceuticals. These tiny energy-producing organelles appear to possess advantages over nuclear transformation, particularly given that each cell may carry hundreds or thousands of such organelles, resulting in the ability to sustain very high numbers of functional gene copies. Transgenic tobacco chloroplasts, for example, can produce human somatotropin at protein levels over a hundred-fold higher than do their nuclear transgenic counterparts, with production of somatotropin and Bt insecticidal protein representing $7 \%$ and $45 \%$ of total plant protein production (10). In the final analyses, the selection of a plant expression system is influenced by cost, safety, and production factors.

Consideration must also be given to where within the plant a pharmaceutical protein is to be produced. Current technology allows gene expression and protein production in either the green matter of the plant (whole plant expression) or selectively in the seed or other tissues through the use of selective promoter systems (11). Production in green mass can produce large amounts of protein (3). Green matters are highly physiologically active and protein levels may be poorly preserved if materials are not rapidly dried or otherwise inactivated $(8,11)$. Thus, unless a protein or peptide is highly stable, green matter production may result in poor protein recovery and usually requires immediate processing. Tuber or root production, while feasible, shares many of the characteristics of green matter production systems. Unlike green matter, seeds generally contain fewer phenolic compounds and a less complex mixture of proteins and have specifically evolved to provide for stable, long-term storage of proteins and other materials in order to assure successful, delayed germination (3). Seeds are therefore an extremely attractive production medium, which can also provide the flexibility to store product for delayed processing.

It is also necessary to decide which plant species to transform for production of a specific pharmaceutical product. While nearly any plant could theoretically be transformed, practical considerations suggest the use of plants with which we are most familiar, and which already have well-established techniques for genetic transformation, high volume production, harvest, and processing. For green matter production, tobacco has usually been the material of choice, largely because of its highly efficient production of biomass (2) although other systems such as alfalfa and even duckweed show promise (12). For seed production, a plant optimized for large seed and high protein production is clearly preferred. Food crop plants have been bred specifically to produce highly productive stands of high-protein seed for which harvesting, processing, and storage technologies are already available. Further, techniques for genetic modification of these plants are well understood, and the extensive history of cultivation and genetic research provides both an understanding of genetic stability and a pool of genetic resources (such as the ability to control pollination using the classical $\mathrm{C}$-male-sterile gene in corn), which facilitate production. This makes food crops highly attractive, with soybean and maize being the obvious choices. This choice, while highly rational, does lead to the potential for the unintended presence of therapeutic protein in human food, and thus necessitates carefully controlled production to avoid the inadvertent presence of therapeutic material in foods, as discussed below. 


\section{Production, safety and efficacy}

Drug research is a unique multi-disciplinary process leading to the development of novel therapeutic agents for disease states that have unmet needs (13). The search for new biopharmaceuticals is driven by a medical need and by the perceived likelihood of technological success, as determined by both therapeutic efficacy and safety parameters. There are several factors to consider for the safety testing of new biopharmaceuticals (14). Because of the protein nature of most biopharmaceutical products; few non-allergic adverse reactions other than those attributable to the primary pharmacological activity are anticipated. Nevertheless, both Good Laboratory Practice and Good Manufacturing Practice, as established for other modes of pharmaceutical production, are essential to plant made pharmaceuticals. Before experimental or clinical use is initiated, it is critical to have fully characterized, contaminant-free materials, as well as appropriate quality assurance so that both the product itself and the therapeutic results will be reproducible. New pharmaceutical agents derived through plant biotechnology must be subjected to the same purity, quality-control, and safety standards as materials derived from bacterial or mammalian cell systems or from other traditional sources such as vaccine production.

Sites used for the cultivation of genetically modified plants have in some cases been disrupted or destroyed by individuals opposed to the use of plant biotechnology, raising additional security concerns. In part, these concerns can be addressed via increased field site monitoring and security, and the use of enclosed environments (greenhouses) for small-scale operations. The relatively small scale and favorable economics of biopharmaceutical operations allow the placement of field operations in geopolitical locations selected for optimal security, with subsequent shipping of raw or processed materials.

Transgenic plants have the added safety feature of freedom from human or animal pathogens (8). Additionally, plant cells are capable of producing complex proteins while largely avoiding the presence of endotoxins in bacterial systems. Endotoxins are often difficult to remove and can contaminate a final product. Thus, there is intrinsic safety and value in using plants as a source of recombinant protein (15). However, as with all plant-derived pharmaceuticals, appropriate measures must be taken to eliminate undesirable plant-derived proteins or other biomolecules and to control the presence of fungal toxins or of pesticides used in plant production (11). Safety evaluations must consider possible non-target organ responses as well as the entire gamut of anticipated and unanticipated side effects as with any bio-pharmaceutical product. Somewhat unique to plant-produced pharmaceuticals are potential effects on non-target species such as butterflies, honeybee, and other wildlife at or near the growing sites. Fortunately, in most instances, the effect on non-target species is limited by the fact that proteins are a normal part of the diet, are readily digested, and are degraded in the environment. Further, many biopharmaceuticals proteins, especially antibodies, are highly species-specific in their effects.

Pharmaceutical production in plants may create the potential for the flow of pharmaceutical materials into the human food chain, especially when food crops are used. This could occur as a result of inadvertent cross-contamination of foodstuffs, through spontaneous growth of genetically engineered plants where they are not desired, or by virtue of pollen flow with some plants (e.g. corn), but not others (e.g. potato). While some have therefore suggested restricting pharmaceutical production to non-food crops such as tobacco, it is the food crops that present the greatest opportunities for efficient production of biopharmaceuticals and that will be most useful for the production of edible vaccines. Because of the potential for adventitious presence in food, care must be exercised in the production of biopharmaceuticals in food crops. Fortunately, acreage requirements for pharmaceutical production are limited, with metric ton protein production being feasible with $>5000$ acres of corn (9). This allows for production under tightly controlled conditions which include production in areas of the country where the crop in question is not routinely grown, the use of physical isolation distances and temporal separation to prevent cross-pollination with food crops, the use of de-tasseling and/or male-sterile traits to control pollen flow, dedicated harvest and storage equipment, and controlled processing separate from all food crops. Unlike commodity crops, plant production of pharmaceuticals should be performed only under tightly controlled conditions similar to those of other pharmaceutical manufacturing; and industry, USDA, FDA, and international organizations have developed production standards jointly (12). These standards are enforced in the US through USDA and FDA, and compliance is further encouraged by the desire of producers to avoid potential liability and infractions. FDA required Good Manufacturing Practice necessitates extensive control of field access, harvest, and product disposition.

While production controls are necessary and appropriate, it should be kept in mind that the majority of therapeutic proteins are not anticipated to have any pharmacological activity when ingested, and are thus unlikely to present a safety issue in the event of accidental contamination of foodstuffs. For example, antibodies, insulin, growth hormone, and most other proteins produce few, if any, systemic pharmacological effects by the oral route. This does not preclude the possibility of local effects on the gastro-intestinal tract or the possibility of immunological effects, as seen in the context of oral vaccines, where such an effect is introduced by design. In fact, one plant-derived antibody directed against epithelial cellular adhesion molecules was withdrawn from clinical development as a result of gastro-intestinal side effects believed to be due to binding to the relevant antigen, which is expressed in the GI tract (8). This is a result of the antigenic specificity of the antibody, and is not attributable to the plant-derived nature of the molecule. While a case-by-case determination of risk will be necessary 
when considering proteins for food crop applications, it appears that the majority of proteins would present no great hazard to the public in the event that control technologies should fail to be fully effective.

\section{The production of pharmaceuticals in plants}

There are a number of recent comprehensive review articles pertaining to production technologies used for molecular farming in plants $(3,8,9,11,15)$. The first commercially produced biopharmaceutical, recombinant human insulin from bacteria, was produced in 1982; an event which coincides roughly with the first development of a genetically modified plant in 1984 (16, 17). This latter development was followed rapidly with a demonstration of the potential of plants for pharmaceutical production with plant expression of human growth hormone fusion protein (18), interferon (19), monoclonal antibodies (20), and serum albumin (21). Since that time, numerous demonstrations of pharmaceutical production in plants have occurred and are described below within three broad categories of therapeutics: antibodies, vaccines, and other therapeutics.

\section{Antibodies}

Monoclonal antibodies (mAbs) have been critical both for the development of biotechnology itself and as products for both therapeutic and diagnostic purposes. Traditional therapeutic monoclonal antibodies have been derived from mice. These proteins were readily identified by the human immune system as foreign, limiting the utility of these antibodies for therapeutic use, especially with repeated dosing (22). Even in the absence of anaphylaxis or serum sickness, the occurrence of neutralizing antibodies that inactivate the drug often precluded further therapeutic use. However, recombinant technologies have allowed murine antibodies to be replaced with partially humanized or chimeric antibodies, and now allow the production of fully human antibodies (22). The latter may be derived from mice carrying the human immunoglobulin genes or produced using yeast or other gene-expression array technologies $(9,22)$. Recombinant technology can also be used to selectively 'evolve' an antibody gene to produce higher affinity binding (affinity maturation) (9). Thus, compared with earlier monoclonal antibodies, current recombinant antibodies exhibit reduced immunogenicity and increased biological activity (22, 23). Recently, the first fully human therapeutic monoclonal antibody has been commercialized (Humira, Adalimumab, Abbott Laboratories), and one would anticipate a low rate of neutralizing antibody development.

Currently, there are over a dozen FDA-approved mAbs, and as many as 700 therapeutic Abs may be under development (9). Plants now have potential as a virtually unlimited source of mAbs, referred to by some as 'plantibodies'. Tobacco plants have been used extensively for antibody expression systems. However, several other plants have been used including potatoes, soybeans, alfalfa, rice and corn. Antibody formats can be full-size, Fab fragments, single-chain antibody fragments, bi-specific scFv fragments, membrane anchored scFv, or chimeric antibodies (see Table 4) (2). Plant cells, unlike mammalian cell expression systems, can express recombinant secretory $\operatorname{Ig} \mathrm{A}(\operatorname{sIg} \mathrm{A})$. $\operatorname{sg} \mathrm{A}$ is a complex multi-subunit antibody that may be useful in topical immunotherapy, and has been successfully expressed in the tobacco plant. Transgenic soybeans are capable of producing humanized antibodies against herpes simplex virus-2. GE corn reportedly is capable of producing human antibodies at yields of up to a kg per acre (9) and has been demonstrated to preserve antibody function through five years of storage under ordinary conditions. 
IOSR Journal of Pharmacy

Vol. 2, Issue 3, May-June, 2012, pp.345-363

Table 4. Recombinant antibodies expressed in transgenic plants

\begin{tabular}{|c|c|c|c|c|c|}
\hline Year & Format & Antibody/Antigen & $\begin{array}{l}\text { Plant } \\
\text { organ }\end{array}$ & $\begin{array}{l}\text { Cellular } \\
\text { location }\end{array}$ & $\begin{array}{l}\text { Transformed } \\
\text { species }\end{array}$ \\
\hline 1989 & IgG1 & Phosphonate ester & Leaf & ER & Tobacco \\
\hline 1990 & IgM & NP hapten & Leaf & $\begin{array}{l}\text { ER } \\
\text { Chloroplast }\end{array}$ & Tobacco \\
\hline 1991 & VH domain & $\begin{array}{l}\text { Substance P } \\
\text { (Neuropeptide) }\end{array}$ & Leaf & $\begin{array}{l}\text { Intra-\& } \\
\text { extra } \\
\text { cellular }\end{array}$ & Tobacco \\
\hline 1992 & scFv & Phytochrome & Leaf & Cytosol & Tobacco \\
\hline 1993 & IgG1 Fab & $\begin{array}{l}\text { Human creatin } \\
\text { kinase }\end{array}$ & Leaf & Nucleolus & Tobacco \\
\hline 1993 & $\mathrm{scFv}$ & Phytochrome & Leaf & Apoplast & Tobacco \\
\hline 1993 & scFv & AMCV & Leaf & Cytosol & N.benthamiana \\
\hline 1994 & IgG & Fungal Cutinase & Root & Apoplast & Tobacco \\
\hline 1994 & IgG1 & $\begin{array}{l}\text { Streptococcus } \\
\text { mutans adhesin }\end{array}$ & Leaf & Apoplast & Tobacco \\
\hline 1995 & $\mathrm{IgA} / \mathrm{G}$ & $\begin{array}{l}\text { Streptococcus } \\
\text { mutans adhesin }\end{array}$ & Leaf & Apoplast & Tobacco \\
\hline 1995 & IgG & TMV & Leaf & Apoplast & Tobacco \\
\hline 1996 & seFv & Cutinase & Leaf & $\mathrm{ER}$ & Tobaeoo \\
\hline 1996 & IgM & RKN seretion & Leaf & Apoplast & Tobacco \\
\hline 1996 & $\mathrm{scFv}$ & BNYVV & Leaf & Apoplast & N.benthamia \\
\hline 1996 & $\mathrm{scFv}$ & Human creatin & Leaf & Apoplast & A.thaliana \\
\hline 1997 & scFv & $\begin{array}{l}\beta-1,4- \\
\text { endoglucanase }\end{array}$ & Root & Chytosol & S.tuberosum \\
\hline 1997 & scFv & Oxazolone & Leaf & ER & Tobacco \\
\hline 1997 & $\mathrm{scFv}$ & Abscisic acid & Leaf & ER & Tobacco \\
\hline 1997 & scFv & Abscisic acid & Seed & ER & Tobacco \\
\hline 1997 & $\mathrm{scFv}$ & CD-40 & Plant & Apoplast & $\begin{array}{l}\text { Tobacco tissue } \\
\text { eulture }\end{array}$ \\
\hline 1998 & scFv & Oxazolone & Tuber & ER & Potato \\
\hline 1998 & $\begin{array}{l}\text { Humanized } \\
\text { IgG }\end{array}$ & HSV-2 & Plant & Secretory & Soybean \\
\hline 1998 & scFv & $\begin{array}{l}\text { Dihydro-flavonol } \\
\text { 4-reductase }\end{array}$ & Leaf & Cytosol & P. hybrida \\
\hline 1999 & IgG & Human IgG & Plant & Apoplast & Alfalfa \\
\hline 1999 & $\mathrm{scFv}$ & CEA & Leaf & $\begin{array}{l}\text { Transient } \\
\text { expression }\end{array}$ & Tobacco \\
\hline 1999 & $\mathrm{seFv}$ & Topoviruses & Plant & $\begin{array}{l}\text { ER, } \\
\text { apoplast }\end{array}$ & $\begin{array}{l}\mathrm{N}: \\
\text { benthamiana }\end{array}$ \\
\hline 1999 & $\mathrm{Bi}-\mathrm{scFv}$ & TMV & Leaf & $\begin{array}{l}\text { ER, } \\
\text { apoplast }\end{array}$ & $\begin{array}{l}\text { Tobacco cell } \\
\text { suspension }\end{array}$ \\
\hline
\end{tabular}


CEA, carcinoembryonic antigen; ER, endoplasmic reticulum; AMCV, artichoke mottle crinkle virus; TMV, tobacco mosaic virus; RKN, root knot nematode; BNYVV, beet necrotic yellow vein virus; HSV-2, herpes simplex virus-2; scFv-IT, scFvbryodin-immunotoxin. N. benthamiana, tobacco (Nicotiana)-related species, A. thaliana, Arabidopsis, an experimental species

Antibodies derived from plants have a multitude of applications, including binding to pathogenic organisms, binding to serum or body fluid effector proteins (e.g. interleukins), binding to tumour antigens to deliver imaging or anti-tumour agents, or binding to a cellular receptor site to up- or down-regulate receptor function. However, plant glycosylation patterns differ from those in mammalian systems, and glycosylation is essential for antibody-mediated activation of complement or the initiation of cellular immune responses $(11,22)$. Plantibodies may carry plant glycoproteins or may be non-glycosylated as a result of genetically deleting glycosylation sites, but are incapable of inducing the latter phenomena in either case (22). This does not appear to be a major limitation, however, since therapeutic applications of monoclonal antibodies are often mediated by binding and inactivation of proteins or receptor molecules and do not require complement or cell-mediated immunity. While glycosylation sequences are poorly immunogenic and hence unlikely to precipitate immunological adverse reactions (8) the presence of mammalian glycosylation sequences not required for therapeutic function may only serve to produce undesired complement- or cell-mediated side effects.

As of 2001, four antibodies expressed in plants had shown potential to be useful as therapeutics (3). A chimeric secretory IgG/IgA antibody effective against a surface antigen of Streptococcus mutans has been expressed in tobacco, and has been demonstrated to be effective against dental caries (24). Soybeans can express a humanized anti-herpes simplex virus (HSV), which has been effective in preventing the transmission of vaginal HSV-2 in animals (25). Rice and wheat expression systems can produce antibodies against carcinoembryonic antigen, which may be useful for in vivo tumor imaging (26). Finally, a plant viral vector has been used to produce a transiently expressed tumor-specific vaccine in tobacco for the treatment of lymphoma (27). Currently, seven plant-derived antibodies have reached the advanced stages of clinical product development (8). These include products directed at the treatment and/or diagnosis of cancer, dental caries, herpes simplex virus, and respiratory syncytial virus. No 'plantibodies' have currently reached the commercialized stage, although at least one product has been tested clinically, and several have been examined in vitro and in animal systems and appear to be equivalent to mammalian-cell-derived analogues (28). Given the high levels of production, purification cost, apparent efficacy, and low immunogenicity of recombinant human antibodies derived from plants, plants appear to hold great potential for future production of monoclonal antibodies.

\section{Vaccines}

There has been considerable interest in developing low-cost, edible (i.e. oral) vaccines. (29, 32). Traditional edible vaccines, as for polio, use whole, attenuated organisms or semi-purified materials to induce both systemic (Ig-G-mediated) and local membrane (Ig-A-mediated) immunity. Plant vaccines can express entire selected proteins, but the use of DNA encoding only desired antigenic sequences from pathogenic viruses, bacteria and parasites has received considerable attention (33). Key immunogenic proteins or antigenic sequences can be synthesized in plant tissues and subsequently ingested as edible subunit vaccines $(30,31,33)$. The mucosal immune system can induce protective immune responses against pathogens or toxins, and may also be useful to induce tolerance to ingested or inhaled antigens $(30,31)$. The production of secretory Ig-A (sIg-A) and provocation of specific immune lymphocytes can occur in mucosal regions, and these regions take on special importance in the development of edible vaccines. Aside from intrinsic low production cost, plant-based vaccines offer a number of unique advantages, including increased safety, stability, versatility, and efficacy (34). Plant produced vaccines can be grown locally where needed, avoiding storage and transportation costs. Relevant antigens are naturally stored in plant tissue, and oral vaccines can be effectively administered directly in the food product in which they are grown, eliminating purification costs $(30,34)$. In many instances, it appears that refrigeration will not be needed to preserve vaccine efficacy, removing a major impediment to international vaccination efforts of the past $(30,33)$. Plants engineered to express only select antigenic portions of the relevant pathogen may reduce immunotoxicity and other adverse effects, and plant-derived vaccines are free of contamination with mammalian viruses. Finally, the development of multi-component vaccines is possible by insertion of multiple genetic elements or through cross-breeding of transgenic lines expressing antigens from various pathogenic organisms.

There are, however, some limitations associated with the use of transgenic plants for vaccine production (10). A major limitation of the expression of recombinant antigens in transgenic plants is obtaining a protein concentration adequate to confer total immunity, given varying protein expression among and within the various plant species. Tight control of expression yields will likely be necessary to reduce variability and assure consistent, effective immunization (10). During the last decade, nearly a dozen vaccine antigens have been expressed in plants (Table 5) (2). Transgenic potatoes can produce antigens of enterotoxigenic $E$. coli heat labile enterotoxin B subunit, and is effective in immunizing against viruses and bacteria that cause diarrhoea. Still other 'edible vaccines' are under development for rabies, foot and mouth disease 
IOSR Journal of Pharmacy

Vol. 2, Issue 3, May-June, 2012, pp.345-363

(veterinary), cholera, and autoimmune diabetes. Transgenic lupin and lettuce plants can express hepatitis B surface antigen. Efforts are underway to develop an 'edible vaccine' against the measles virus using the tobacco plant. A plant-based oral subunit vaccine for the respiratory syncytial virus (RSV) using either the apple or the tomato is under development (30).

Table 5. Recombinant vaccines expressed in plants

\begin{tabular}{|c|c|c|}
\hline Year & Vaccine antigen & Species \\
\hline 1992 & $\begin{array}{l}\text { Hepatitis virus B surface } \\
\text { antigen }\end{array}$ & Tobacco \\
\hline 1995 & Malaria parasite antigen & Virus particle* \\
\hline 1995 & $\begin{array}{l}\text { Escherichia coli heat-labile } \\
\text { enterotoxin }\end{array}$ & Tobacco, Potato \\
\hline 1995 & Rabies virus glycoprotein & Tomato \\
\hline 1996 & $\begin{array}{l}\text { Human rhinovirus } 14 \text { (HRV- } \\
\text { 14) and human } \\
\text { immunodeficiency virus type } \\
\text { (HIV-1) epitopes }\end{array}$ & Virus particle* \\
\hline 1996 & Norwalk virus capsid protein & Tobacco,Potato \\
\hline 1997 & $\begin{array}{l}\text { Diabetes-associated } \\
\text { autoantigen }\end{array}$ & Tobacco, Potato \\
\hline 1997 & Hepatitis B surface proteins & Potato \\
\hline 1997 & Rabies and HIV epitopes & Virus particle* \\
\hline 1997 & Mink Enteritis Virus epitope & Virus particle* \\
\hline 1998 & $\begin{array}{l}\text { Foot and mouth disease virus } \\
\text { VP1 structural protein }\end{array}$ & Arabidopsis \\
\hline 1998 & $\begin{array}{l}\text { Escherichla coli heat=lable } \\
\text { enterotoxin }\end{array}$ & Potato \\
\hline 1998 & $\begin{array}{l}\text { Escherichia coli heat-labile } \\
\text { enterotoxin }\end{array}$ & Potato \\
\hline 1998 & Rabies virus & Virus particle* \\
\hline 1998 & Cholera toxin B subunit & Potato \\
\hline 1998 & $\begin{array}{l}\text { Human insulin-Cholera toxin } \\
\text { B subunit fusion protein }\end{array}$ & Potato \\
\hline 1999 & $\begin{array}{l}\text { Foot and mouth disease virus } \\
\text { VP1 structural protein }\end{array}$ & alfalfa \\
\hline 1999 & $\begin{array}{l}\text { Hepatitis B virus surface } \\
\text { antigen }\end{array}$ & $\begin{array}{l}\text { Yellow hupin, } \\
\text { lettuce }\end{array}$ \\
\hline 1999 & $\begin{array}{l}\text { Human cytomegalovirus } \\
\text { glycoprotein B }\end{array}$ & Tobacco \\
\hline 1999 & Dental caries $(S$. mutans $)$ & Tobacco \\
\hline 1999 & $\begin{array}{l}\text { Diabetes-associated } \\
\text { autoantigen }\end{array}$ & Tobacco, Carrot \\
\hline 2002 & Respiratory syncytial virus & Tomato \\
\hline
\end{tabular}

* Plant Virus - can be expressed in multiple plant species

The plant species to be used for the production and delivery of an oral vaccine can be specifically selected to achieve desired goals. A large number of food plants (e.g. alfalfa, apple, asparagus, banana, barley, cabbage, canola, cantaloupe, carrots, cauliflower, cranberry, cucumber, eggplant, flax, grape, kiwi, lettuce, lupins, maize, melon, papaya, pea, peanut, pepper, plum, potato, raspberry, rice, service berry, soybean, squash, strawberry, sugar beet, sugarcane, sunflower, sweet potato, tomato, walnut, and wheat) have been transformed (29). Many of the high volume, high acreage plants such as corn, 
soybeans, rice, and wheat may offer advantages. Corn, since it is a major component in the diet of the domestic animal, is a good candidate for vaccine production. In humans, particularly infants, the plant of choice to produce the vaccine might be the banana. Bananas are a common component of many infant diets and can be consumed uncooked, thus eliminating the possibility of protein denaturation due to high temperatures. Unfortunately, it is relatively difficult to create transgenic bananas and the production time is longer than for certain other food crops. Cereals and other edible plants are advantageous for vaccine production over plant species such as tobacco because of the lower levels of toxic metabolites. It is evident that there are numerous opportunities to identify and develop low-cost plant derived vaccine materials, including edible plantbased vaccines.

\section{Other therapeutic agents}

A wide variety of other therapeutic agents have been derived from plants (Tables 6, 7), including hormones (somatotropin), enzymes, interleukins, interferons (IFN) and human serum albumin (HSA) (2, 23). Similar biotherapeutic agents have also been expressed from mammalian and bacterial cell systems (4). There is a worldwide demand for HSA, and plant production would offer the advantage of freedom from contamination with human pathogenic viruses. Modified rice plants are capable of producing human alpha-1-antitrypsin, a protein that may realize therapeutic potential in emphysema and hepatic diseases. Hirudin, originally isolated from leeches, is a blood anticoagulant that can now be expressed from oilseed rape, from tobacco and from mustard. Transgenic potato plants can encode for at least two subtypes of human INF, some of which may moderate certain cancers and diseases caused by viral agents.

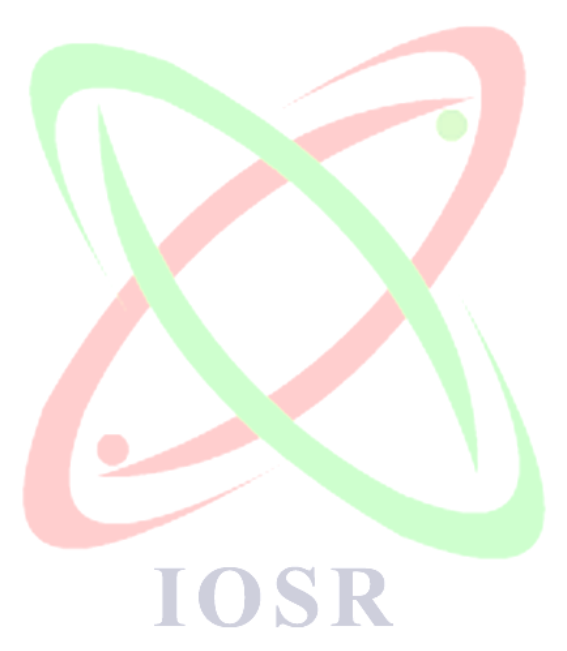


Table 6. Biopharmaceuticals derived from transgenic plants

Potential Plant Protein
application/indication

\section{Anticoagulants}

Protein C pathway

Indirect thrombin

inhibitors

Recombinant

hormones/proteins

Neutropenia

Anaemia

Antihyperanalgesic by opiate activity

Wound repair/control of cell proliferation

Hepatitis B and C treatment

Liver cirrhosis

Blood substitute

Collagen

Protein/peptide inhibitors

Cystic fibrosis, liver disease and haemorrhage

Trypsin inhibitor for transplantation surgery
Tobacco

Ethiopian

mustard

Tobacco

Human granulocytemacrophage colonystimulating factor

Human protein $\mathrm{C}$ (serum protease)

Human hirudin variant 2

AMT

AMT

AMT

AMT

Tobacco

Human erythropoietin

AMT

Human erythropoietin

AMT

Thale cress, Human enkephalins

Human interferon- $\alpha$

AMT

Rice, turnip

Potato, tobacco

Human serum albumin

AMT

Tobacco

Human haemoglobin

AMT

Tobacco

Human homotrimeric collagen

AMT 
Table 7. Selected pharmaceutical proteins expressed in transgenic plants

Year Protein

1986 Human growth hormone

1990 Human serum albumin

1993 Human epidermal growth factor

1994 Trout growth factor

1994 Human $\alpha$-interferon

1995 Hirudin

1995 Erythropoietin

1996 Glucocerebrosidase, human protein C serum protease

1997 Human and $ß$ haemoglobin

1997 Human muscarinic cholinergic receptors

1997 Murine granulocyte- macrophage colony stimulating factor

1998 Interleukin-2 and interleukin-4

1999 Human placental alkaline phosphatase

1999 Human $\alpha$-l-antitrypsin

2000 Human growth hormone (somatotropin)

2000 Human growth hormone (somatotropin)
Species

Tobaeco

Sunflower

Tobacco

Potato

Tobacco

Tobacco

Rice

Tobacco

Suspension cells

Tobacco

Suspension cells

Tobacco

Tobacco

Tobacco

Tobacco

Tobacco

Suspension cells

Tobacco

Rhizosecretion

Rice

Suspension cells

Tobacco seeds

Tobacco

chloroplasts 
Erythropoietin (EPO) has also been expressed in transgenic tobacco plants. Erythropoietin, a glycoprotein used to treat anaemias, was commercialized from mammalian systems nearly 20 years ago. Blood substitutes such as human haemoglobin have long been pursued, and human haemoglobin derived from transgenic tobacco is being tested to ensure the molecule's function and oxygen-carrying capacity (35). In general, the levels of pharmaceutical proteins produced by transgenic plants have been low, often $<1 \%$ of total soluble protein. While this is quite sufficient to allow for economical production of highly active pharmaceutical molecules, improved technologies for high level expression of protein will be probably needed to allow practical production of high volume human replacement proteins such as HSA (Human serum albumin) (3) haemoglobin or blood coagulation factors.

\section{Basis for immunogenicity to biopharmaceuticals}

Most biopharmaceuticals induce immune responses (immunogenicity), which in many cases do not have clinically relevant consequences. However, in some cases the consequences can be severe and potentially lethal, causing a loss of efficacy of the drug or even worse, leading to autoimmunity to endogenous molecules. In case of exogenous protein products (neo-antigens or non-self antigens), such as biopharmaceuticals derived from non-human origin (microbial, plant or animal), the immune response to the foreign protein leads to neutralizing antibodies. This immune response is mediated by $\mathrm{T}$ cells and occurs as a fast reaction after first meeting the antigen.

The immune response to endogenous proteins of human origin (self-antigen), such as human recombinant DNA products, leads to binding antibodies. B cells through the breakdown of immune tolerance mediate this response, and the reaction develops slowly and disappears after treatment withdrawal.

The theoretical basis for immunogenicity to biopharmaceuticals is based on their foreign nature, being of exogenous origin (neo-antigens or non-self antigens), or their similarity to self molecules (self antigens). In both cases, it is the activation of antibody-secreting B cells that leads to the clinical manifestation of immunogenicity.

There are two ways in which such immunogenicity can occur. First impurities, such as endotoxins or denatured proteins within a biopharmaceutical may provide a second, so-called 'danger' signal to T cells that may then send activating signals to B cells and hence, break B-cell tolerance. Second, B-cell tolerance can be broken via a T-cell independent response. If a biopharmaceutical for instance is not uniformly soluble it can form aggregates (Figure 3). The immune system may confuse these aggregates with viruses, and B cells are activated to proliferate and produce auto-reactive binding antibodies.

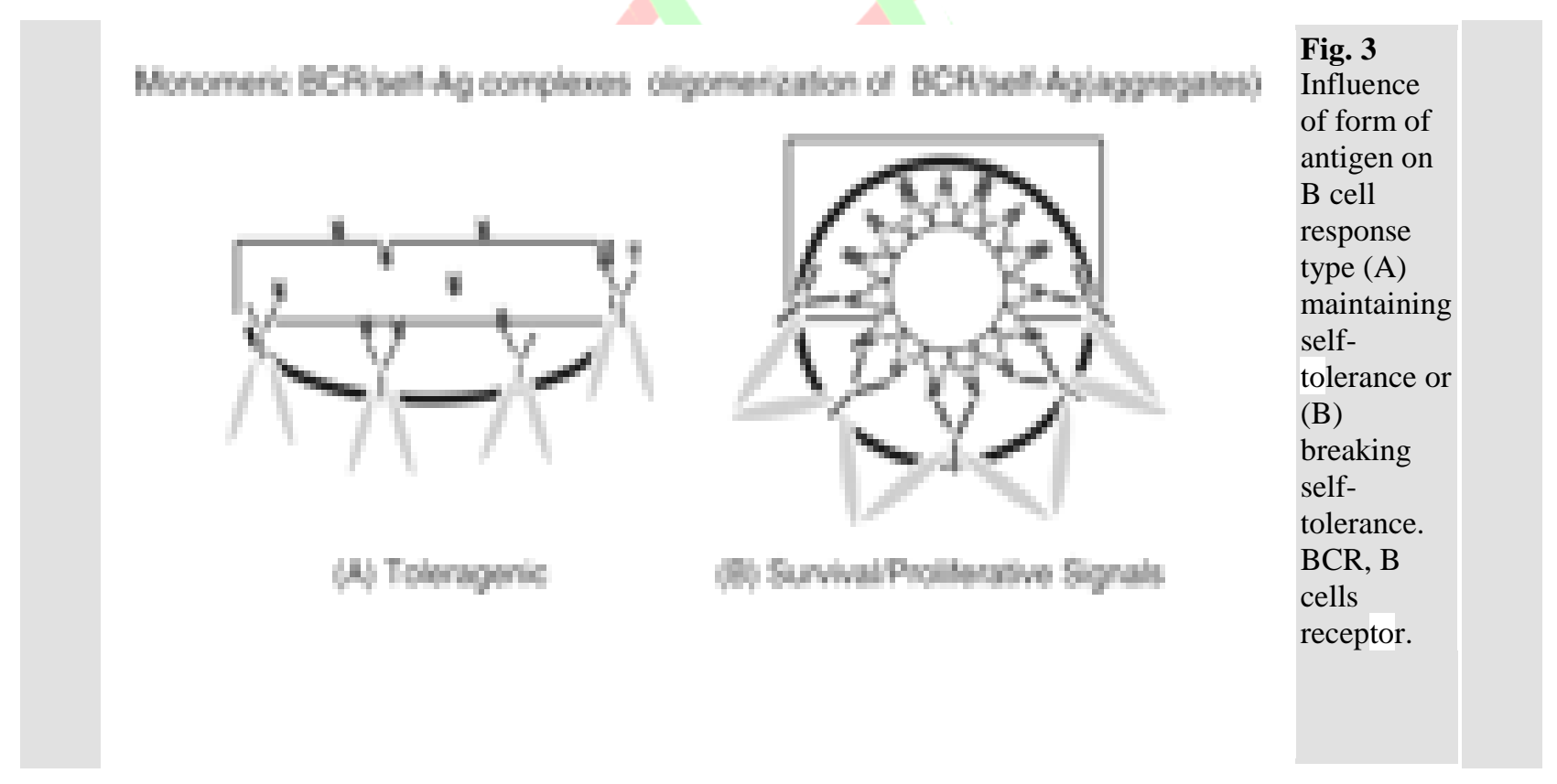

\section{Factors contributing to immunogenicity \\ Product-related factors}

There are documented product- and host-related factors leading to immunogenicity of biopharmaceuticals (36). Productrelated factors include structural properties, such as protein sequence, the presence of exogenous or endogenous epitopes and the degree of glycosylation influencing protein degradation, exposure of antigenic sites and solubility. The higher immunogenicity of an Escherichia coli-derived IFNß product has been linked to the lack of glycosylation compared with 
other Chinese hamster ovary (CHO) cell-derived products (37). Other product-related factors influencing immunogenicity are formulation and storage, downstream processing and the level of impurity or presence of contaminants. Evidence for the importance of these factors can be found in the reported variation in antigenicity of IFNß products produced at different manufacturing sites (38). Changing the formulation and storage of IFN $\alpha$ 2a has been shown to lower immunogenicity (38). Further documented examples include the effect of downstream processing on the immunogenicity of factor VIII and the induction of antibodies against insulin and growth hormone due to product impurity $(39,40)$.

\section{Host-relatedfactors}

Several host-related factors affect the immunogenicity of a biopharmaceutical. The genetic predisposition of a patient may influence the production of neutralizing antibodies. For example, the major histocompatibility complex (MHC) allele affects host recognition of antigen in T-cell mediated responses. Alternatively, the genetic sequence encoding the endogenous equivalent of the therapeutic protein may play a role. Haemophilia A patients treated with factor VIII have been shown to have different probabilities of developing immunogenicity depending on their endogenous expression of the protein $(41,42)$. Patients with genetic deletion of factor VIII recognized it as foreign and produced neutralizing antibodies against it. Patients with genetic deletion of factor VIII recognized it as foreign and produced neutralizing antibodies against it. Concomitant illnesses, particularly of the kidney and liver, may also influence immunogenicity. Autoimmune diseases predispose patients to producing antibodies against therapeutic proteins. Dose and route of administration are important determinants. Higher doses or prolonged duration of treatment increase exposure and thereby heighten the risk of developing immunogenicity. Immunogenicity appears to be greater if the biopharmaceutical is administered subcutaneously (SC) or intramuscularly and has decreasing severity with intravenous and local administration (43).

\section{Consequence of immunogenicity to biopharmaceuticals}

In many cases, the presence of antibodies has little or no biological and clinical consequence. However, even in case of wellestablished innovator biopharmaceutical products, biological and clinical consequences of immunogenicity have been observed. The most common biological effect is the loss of efficacy, as has been described for IFN $\alpha$ and $\beta$ (40). The loss of efficacy may be restored with increasing dose such as Factor VIII for haemophilia A patients (40). Clinical consequences may be manifested in general immune effects, such as anaphylaxis, allergic reactions or serum sickness. These have been relatively common historically but have become less common with the increasing availability of highly purified products and more stringent regulation of established biopharmaceuticals. Major clinical impact is seen, however, if a natural protein with essential biological activity is neutralized. Such consequences have been described in the case of megakaryocyte-derived growth factor (MDGF), where antibodies against the biopharmaceutical also neutralized endogenous thrombopoietin leading to severe thrombocytopenia (44). An upsurge in the incidence of antibody-mediated pure red cell aplasia (PRCA) observed outside the US between 2000 and 2002 revealed that a small change in the formulation of a well-established innovator product with extensive patient years experience may have significant clinical consequences $(45,46)$. The PRCA cases were associated with a breakdown of immune tolerance to erythropoietin treatment resulting in neutralizing antibody formation not only against the recombinant protein, but also the native erythropoietin (47). The sharp increase in incidence occurred

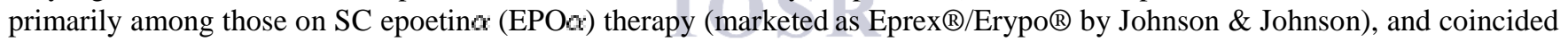
with replacement of human serum albumin as stabilizer by glycine and polysorbate 80 in 1998. Subsequent withdrawal of the $\mathrm{SC}$ formulation of EPO $\alpha$ led to a considerable decrease in the incidence of PRCA cases.

A number of possible mechanisms have been proposed to explain the observed upsurge of PRCA. The modification in the drug formulation probably played a major role (47). The role of leachates has been investigated (48), although results failed to show their significant effect in immune responses. This direction of investigation was based on the observation that among patients receiving SC EPO $\alpha$ from syringes with Teflon-coated stoppers, the incidence of PRCA was lower. The role of micelles (polysorbate 80 plus EPO $\alpha$ ) is currently under investigation (49). It is nevertheless likely that the immunogenicity of this particular product has been enhanced by the way the product was stored, handled and administered. Most certainly a combination of factors contributed to the reduced incidence of PRCA by 2003. The case of PRCA has two-fold relevance with regard to quality and safety of biopharmaceutical and biosimilar products. Although the innovator product has been in use for years, it took time until the link between the relatively small modification in the product formulation and the upsurge of PRCA cases was established. The picture becomes even more complex when biosimilar products are considered. Even when biosimilars are produced from the same genetic construct, using the same technique, formulation and packaging as the innovator product, there is no guarantee that they are comparable with the reference product. Bioassays of follow-up EPO $\alpha$ preparations manufactured in India, Asia and South America show their dissimilarities compared with the innovator EPO $\alpha$ product, despite their claimed substitutability and bioequivalence. 


\section{Measuring immunogenicity}

Assessing the immunogenicity of biopharmaceuticals is becoming increasingly important with the emergence of biosimilar agents. Essentially there are two main types of assays: the radioimmunoprecipitation assays (RIPA) and enzyme-linked immunosorbent assays (ELISA) which determine binding antibodies, while bioassays identify the presence of neutralizing antibodies (50). These assays are usually used in conjunction. Patient sera are first screened for the presence of binding antibodies and, if positive, the presence of neutralizing antibodies is tested for with the more cumbersome bioassay.

When a biopharmaceutical has unique determinants, assays become highly product specific. One problem is that quality assurance assays for biopharmaceuticals are less sensitive and precise than are tests for small molecules, hence it is difficult to analyse impurities (36). The timing of sample collection may also influence assay results-immunogenicity typically develops after prolonged treatment. No single technique is available to predict immunogenicity of a biopharmaceutical product (51). Methods used in different laboratories undertaking bioassays vary not only according to how antibody levels are determined but also the way results are reported. Comparison of assay results between studies, and laboratory sites face immense difficulties without international standardization of the assay procedures and data presentation (52).

\section{Future directions}

The use of plants as factories for the production of novel vaccines, antibodies and other therapeutic proteins will undoubtedly continue to develop. Molecular farming may become the premier expression system for a wide variety of new biopharmaceuticals and 'plantibodies'. Important economic advantages will likely be realized as the technology continues to evolve and improve. Efforts will need to focus on increasing yields, on scale-up of production, on distribution and handling of transgenic plant material, and on the development and validation of production techniques, which effectively isolate pharmaceutical production from human and animal food. Plant-derived biopharmaceuticals will need to meet the same safety and efficacy standards as those products obtained from non-plant sources. There will be a need for continued vigilance to safeguard the environment, ensuring that errant substances do not affect non-target organisms. Gene containment methodologies will continue to develop, and there must be safeguards against the over-expression of potentially harmful proteins in transgenic pollen. Undoubtedly, there will be a continuing debate about the use of transgenic food plants, as opposed to non-food plants, for producing new pharmaceuticals. The advantages of recombinant plant DNA technology for the production of antibodies, vaccines, other pharmaceuticals, and even high-volume plasma proteins are becoming increasingly apparent. As the technology involves, it appears highly likely that plant-derived pharmaceuticals will play a significant role in the future of clinical therapeutics.

\section{ACKNOWLEDGEMENTS:}

Author is highly grateful to University Grants Commission, New Delhi for providing grants to do work in this area of Biopharmaceuticals.

\section{REFERENCES}

1. Winslow LC, Kroll DJ. Herbs as medicines. Arch Intern Med 1998; 158:2192-9.

2. Fischer R, Emans N. Molecular farming of pharmaceutical proteins. Transgen Res 2000; 9:279-99.

3. Daniell H, Streatfield SJ, Wycoff K. Medical molecular farming: production of antibodies, biopharmaceuticals and edible vaccines in plants. Trends Plant Sci 2001; 6:219-26.

4. Thomas JA. Biotechnology: Safety evaluation of biotherapeutics and agribiotechnology products. In: Thomas JA, Fuchs RL, eds. Biotechnology and safety assessment. New York, Academic Press, 2002:347-84.

5. Walsh G. Biopharmaceutical Benchmarks, 2003. Nature Biotechnol. 2003; 21:865-70.

6. PhRMA. 2002 Survey-New medicines in development-Biotechnology. Washington DC, Pharmaceutical Manufacturers Association of America, 2002.

7. HighTech Business Decisions Report. Biopharmaceutical Contract Manufacturing: Meeting Demand for Increased Capacity, Vol. 1, Chapter 3. Moraga CA, High Tech Business Decisions, 2001.

8. Ma JKC, Drake PMW, Christou P. The production of recombinant pharmaceutical proteins in plants. Nature Rev Genet 2003; 4:794-805.

9. Humphreys DP, Glover DJ. Therapeutic antibody production technologies: molecules, applications, expression, and purification. Curr Opin Drug Discover Dev 2001; 4:172-85.

10. Chargelegue D, Obregon P, Drake PMW. Transgenic plants for vaccine production: Expectations and limitations. Trends Plant Sci 2001; 6:495-6.

11. Russell DA. Feasibility of antibody production in plants for human therapeutic use. Curr Topics Microbiol 1999; 240:119-38. 
12. BIO (Biotechnology Industry Organization). Fact Sheet Number Five: Growing plants for pharmaceutical production vs. for food and feed crops. Washington DC, BIO, 2003.

13. Panchagnula R, Thomas NS. Biopharmaceutics and pharmacokinetics in drug research. Int $J$ Pharmaceutics 2000; 201:131-50

14. Thomas JA. Recent developments and perspectives of biotechnology-derived products. Toxicology 1995; 105:7-22.

15. Fischer R, Hoffmann K, Schillberg A, Emans N. Antibody production by molecular farming in plants. $J$ Biol Regul Hemeost Agents 2000; 14:83-92.

16. Fraley RT, Rogers SG, Horsch RB, et al. Expression of bacterial genes in plant cells. Proc Natl Acad Sci USA $1983 ; 80: 4803-7$

17. Horsch R, Fry JE, Hoffman N, Eicholtz D, Rogers S, Fraley R. A simple and general method for transferring genes into plants. Science 1985; 227:1229-31.

18. Barta A, Sommergruber K, Thompson D, Hartmuth K, Matzke M, Matzke A. The expression of a nopaline synthase- human growth hormone chimeric gene in transformed tobacco and sunflower callus tissue. Plant Mol Biol 1986; 6:347-57.

19. DeZoeten GA, Penswick JR, Horisberger MA, Ahl P, Schultze M, Hohn T. The expression, localization, and effect of a human interferon in plants. Virology 1989; 172:213-22.

20. Hiatt A, Cafferkey R, Bowdish K. The production of antibodies in transgenic plants. Nature 1989; 342:76-8.

21. Sijmons OC, Dekker BMM, Schrammeijer B, Vorwoerd RC, van den Elzen PJM, Hoekema A. Production of correctly processed human serum albumin in transgenic plants. Bio/Technology. 1990; 8:217-21.

22. Breedveld FC. Therapeutic monoclonal antibodies. Lancet 2000; 355:735-40.

23. Ma JK, Hikmat BY, Wycoff K, Vine ND, Chargelegue D, Yu L, Hein MB, Lehner T. Characterization of a recombinant plant monoclonal secretory antibody and preventive immunotherapy in humans. Nature Med 1998; 4:601-6.

24. Giddings G. Transgenic plants as protein factories. Curr Opin Biotechnol 2001; 12:450-4.

25. Zeitlin L, Olmsted SS, Moench TR, Co MS, Martinell BJ, Paradkar VM, Russell DR, Queen C, Cone RA, Whaley KJ. A humanized monoclonal antibody produced in transgenic plants for immunoprotection of the vagina against genital herpes. Nature Biotechnol 1998; 16:1361-4.

26. Stoger E, Vaquero C, Torres E, Sack M, Nicholson L, Drossard J, Williams S, Keen D, Perrin Y, Christou P, Fischer R. Cereal crops as viable production and storage systems for pharmaceutical scFv antibodies. Plant Mol Biol 2000; 42:583-90.

27. McCormick AA, Kumagai MH, Hanley K, Turpen TH, Hakim I, Grill LK, Tuse D, Levy S, Levy R. Rapid production of specific vaccines for lymphoma by expression of the tumor-derived single-chain Fv epitopes in tobacco plants. Proc Natl Acad Sci USA 1999; 96:703-8.

28. Eppard P. Monsanto Company. Personal communication.

29. Richter L, Kipp PB. Transgenic plants as edible vaccines. Curr Topics Microbiol Immunol 1999; 240:159-76.

30. Korban SS, Krasnyanski SF, Buetow DE. Foods as production and delivery vehicles for human vaccines. $J$ Am Coll Nutr 2002; 21 (suppl.):212-17S.

31. Tacket CO, Mason HS. A review of oral vaccination with transgenic vegetables. Microbes Infection 1999; 1:777-83.

32. Giddings G, Allison G, Brooks D, Carter A. Transgenic plants as factories for biopharmaceuticals. Nature Biotechnol 2000; 18:1151-5.

33. Mahon BR, Moore A, Johnson PA, Mills KHG. Approaches to new vaccines. Crit Rev Biotechnol 1998; $18: 257-82$.

34. Streatfield SJ, Jilka JM, Hood EE, Turner DD, Baily MR, Mayor JM, Woodard SL, Beifuss KK, Horn ME, Delaney DE, Tizard IR, Howard JA. Plant-based vaccines: unique advantages. Vaccine 2001; 19:2742-8.

35. Theisen M. Production of recombinant blood factors in transgenic plants. In: Shahidi et al., eds. Chemicals via Higher Plant Bioengineering. New York, Kluwer Academic/Plenum Publishers, 1999:211-20.

36 Schellekens H. (2005) Factors influencing the immunogenicity of therapeutic proteins. Nephrol Dial Transplant 20(6): 3-9.

37 Karpusas M, Whitty A, Runkel L, Hochman P. (1998) The structure of human interferon-beta: implications for activity. Cell Mol Life Sci 54:1203-1216.

38 Ryff JC. (1997) Clinical investigation of the immunogenicity of interferon-alpha 2a. J Interferon Cytokine Res 17(1): S29-S33. 
39 Moore WV and Leppert P. (1980) Role of aggregated human growth hormone (hGH) in development of antibodies to hGH. J Clin Endocrinol Metab 51:691-697.

40 Patten PA and Schellekens H. (2003) The immunogenicity of biopharmaceuticals. Lessons learned and consequences for protein drug development. Dev Biol 112:81-97.

41 Thompson AR, Murphy ME, Liu M, et al. (1997) Loss of tolerance to exogenous and endogenous factor VIII in a mild hemophilia A patient with an Arg593 to Cys mutation. Blood 90:1902-1910.

42 Fakharzadeh SS and Kazazian HH Jr. (2000) Correlation between factor VIII genotype and inhibitor development in hemophilia A. Semin Thromb Hemost 26:167-171.

43 Porter S. (2001) Human immune response to recombinant human proteins. J Pharm Sci 90:1-11.

44 Neumann TA and Foote M. (2000) Megakaryocyte growth and development factor (MGDF): an Mpl ligand and cytokine that regulates thrombopoiesis. Cytokines Cell Mol Ther 6:47-56.

45 Casadevall N, Nataf J, Viron B, et al. (2002) Pure red-cell aplasia and antierythropoietin antibodies in patients treated with recombinant erythropoietin. $N$ Engl J Med 346:469-475.

46 Johnson \& Johnson Pharmaceutical Research \& Development. (2005) Summary of PRCA case reports: update on the actions by Johnson \& Johnson Pharmaceutical Research \& Development regarding erythropoietin antibody-positive pure red cell aplasia. Johnson \& Johnson Pharmaceutical Research \& Development.

47 Schellekens H. (2005) Immunologic mechanisms of EPO-associated pure red cell aplasia. Best Pract Res Clin Haematol 18:473-480.

48 Boven K, Knight J, Bader F, et al. (2005) Epoetin-associated pure red cell aplasia in patients with chronic kidney disease: solving the mystery. Nephrol Dial Transplant 20 (3): 33-40.

49 Louet S. (2003) Lessons from Eprex for biogeneric firms. Nat Biotechnol 21:956-957.

50 Schellekens H, Ryff JC, van der Meide PH. (1997) Assays for antibodies to human interferon-alpha: the need for standardization. J Interferon Cytokine Res 17: S5-S8.

51 Koren E, Zuckerman LA, Mire-Sluis AR. (2002) Immune responses to therapeutic proteins in humans-clinical significance, assessment and prediction. Curr Pharm Biotechnol 3:349-360.

52 Kromminga A and Schellekens H. (2005) Antibodies against erythropoietin and other protein-based therapeutics: an overview. Ann NY Acad Sci 1050:257-265.

53 Farnsworth NR, Blowster RN, Darmratoski D, Meer WA, Cammarato LV (1967) Studies on Catharanthus alkaloids IV Evaluation by means of TLC and ceric ammonium sulphate spray reagent, Lloydia 27: 302-314.

54 Farnsworth NR, Bingel AS. Problems and prospects of discovery new drugs from higher plants by pharmacological screening. In: H.Wagner and P.Wolff (eds.), New Natural products and plant drugs with pharmacological, biological and therapeutical activity, Springer Verlag, Berlin 1997: 1-22.

55 Perumal Samy R, Ignacimuthu S (1998): Screening of 34 Indian medicinal plants for antibacterial properties. $J$. Ethnopharmacol. 62: 173-182.

56 Chatterjee, I. Chakravarty, A.K., Gomesa A., (2006) Daboia russellii and Naja kaouthia venom neutralization by lupeol acetate isolated from the root extract of Indian sarsaparilla Hemidesmus indicus R.Br . Journal of Ethnopharmacology 106(1), 38-43.

57 Alam, M.I., Auddy, B., Gomes, A., 1994. Isolation and partial characterization of viper venom inhibiting factor from the root extract of the Indian medicinal plant sarsaparilla (Hemidesmus indicus R.Br.). Toxicon 32, 15511557.

58 Chatterjee, I., Chakravarty, A.K., Gomes, A., 2004. Antisnake venom activity of ethanolic seed extract of Stychnos nux vomica Linn. Indian Journal of Experimental Biology 42, 468-475.

59 Adailkan, P.G., Gauthaman, K., 2001. History of herbal medicines with an insight on the pharmacological properties of Tribulus terrestris. The Aging Male 4, 163-169.

60 Heinrich, M., 2000. Plant resources of south-east Asia medicinal and poisonous plants 1. Phytochemistry 53, 619-620.

61 Pfister, J.A., Ralphs, M.H., Gardner, D.R., Stegeleier, B.L., Manners, G.D., Panter, K.E., 2002. Management of three toxic Delphinium species based on alkaloid concentrations. Biochemical Systematics and Ecology 30, $129-138$. 